\title{
Effects of Pomiferin Premedication on the Antioxidant Status of Rats with Ischemia-Reperfused Kidney
}

\author{
E. JANOŠTÍKOVÁ, L. BARTOŠÍKOVÁ, J. NEČAS, J. JUŘICA*, T. FLORIAN, \\ T. BARTOŠÍK**, J. KLUSÁKOVÁ**, V. SUCHÝ, M. LIŠKOVÁ, M. FRYDRYCH \\ Pharmaceutical Faculty, University of Veterinary and Pharmaceutical Sciences Brno \\ *Faculty of Medicine, Masaryk University in Brno \\ ** St. Anne Teaching Hospital, Brno
}

Received February 2, 2005

Accepted October 3, 2005

\begin{abstract}
E. Janoštíková, L. Bartošíková, J. Nečas, J. Juřica, T. Florian, T. Bartošík, J. Klusáková, V. Suchý, M. Lišková, M. Frydrych: Effects of Pomiferin Premedication on the Antioxidant Status of Rats with Ischemia-Reperfused Kidney. Acta Vet. Brno 2005, 74: 557-564.

The aim of this study was to analyze the relationship between the antioxidant effect and the dose of pomiferin during a prophylactic administration. The pathological model for an in vivo experiment was the unilateral ischemia-reperfusion of the laboratory rat kidney. The animals were randomly divided into five groups. Pomiferin was administered orally at doses of 5, 10 and 20 $\mathrm{mg} \cdot \mathrm{kg}^{-1}$, in $2 \mathrm{ml}$ of Avicel solution by a gastric sound once a day to three premedicated groups. A placebo - $2 \mathrm{ml}$ of $0.5 \%$ Avicel solution - was given to the fourth group, and the fifth group was intact. The premedication lasted 15 days and subsequently ischemia of the left kidney was incited under a general anaesthesia for $60 \mathrm{~min}$. The reperfusion lasted $10 \mathrm{~min}$ and it was concluded with blood collection from the left ventricle, and the reperfused kidney was recovered. Selected biochemical markers were assessed in blood: superoxide dismutase, glutathione peroxidase, total antioxidant capacity and malondialdehyde. Kidney tissue samples were used for histopathological examination. Biochemical and histopathological results confirmed the anticipated effects of pomiferin. Pomiferin supported the defensive reactions of the system against free radicals and decreased lipid peroxidation in cell membranes. The relation between the effect and the dose of pomiferin was not linear, and some of the assessed differences between the groups were statistically highly significant. The best results of the biochemical examination were achieved after the administration of pomiferin at the dose of $20 \mathrm{mg} \cdot \mathrm{kg}^{-1}$. The histopathological results confirmed the dose of $5 \mathrm{mg} \cdot \mathrm{kg}^{-1}$ to be the most effective one.
\end{abstract}

Antioxidant capacity, dose, flavonoid, glutathion peroxidase, ischemia-reperfusion, pomiferin, superoxide dismutase

All biological systems are permanently in contact with reactive oxygen or nitrogen species (ROS/RNS) - so-called "free radicals". These come from external sources or originate endogenously during physiological processes. The delicate balance between the cellular antioxidant defence and the generation of ROS is important for maintaining homeostasis. An imbalance in the oxidant-antioxidant activity is called the oxidative stress and may lead to many free radical mediated pathologies.

ROS play an important role in the pathogenesis of an ischemia/reperfusion (I/R) injury to the kidney (Singh and Chopra 2004; Serteser et al. 2002). Ischemia has many biological effects, including decreased levels of ATP, increased levels of calcium, and an alteration in the membrane lipids and enzyme activities. One of the most important changes during ischemia is the conversion of xanthine dehydrogenase to xanthine oxidase (XOD). With reperfusion - the re-oxygenation of the ischemized tissue - XOD generates ROS (Roy 1982). ROS modify cell membrane lipids, proteins, and nucleic acids, and induce structural and functional damages to the cells (Shimizu et al. 2004). ROS induce the synthesis of adhesive molecules and thus attract neutrophils - the producers of other ROS molecules (Drábiková et al. 2002).

Phone: +420541562892

Fax: +420 541240605

E-mail: bartosikoval@vfu.cz

http://www.vfu.cz/acta-vet/actavet.htm 
Renal ischemia is a common cause of an acute renal failure. Ischemic cell injury to the kidney occurs during a cardiovascular surgery (Bartošová et al. 2003), renal transplantation, early allograft rejection subsequent to a renal transplantation, etc.

The therapy of an ischemic injury is complicated. It is more effective to prevent the origin of ROS. It is possible to strengthen the natural antioxidant mechanisms by the administration of compounds which act as free radical scavengers (Nečas et al. 1997; B artošíková et al. 1998, 2004, 2004; Janoštíková et al. 2004; Pečivová et al. 2004).

The flavonoids are a heterogeneous group of phenol compounds (approx. 4000), ubiquitous in the plant kingdom. Many positive as well as negative effects of flavonoids have been documented (Rice-Evans 1995; Van Hoorn et al. 2002).

Flavonoids have their own antioxidant capacity and they are able to regulate enzymes such as xanthine oxidase, phospholipase and nitric oxide synthase. They can inhibit peroxynitrite in activated macrophages (Rice-Evans 1995; Van Hoorn et al. 2002).

Pomiferin (see Fig. 1) belongs to the group of prenylated isoflavones. The compound was isolated from the fruits of Maclura pomifera (Raf.) Schneid. (Moraceae) (Veselá et al. 2003).

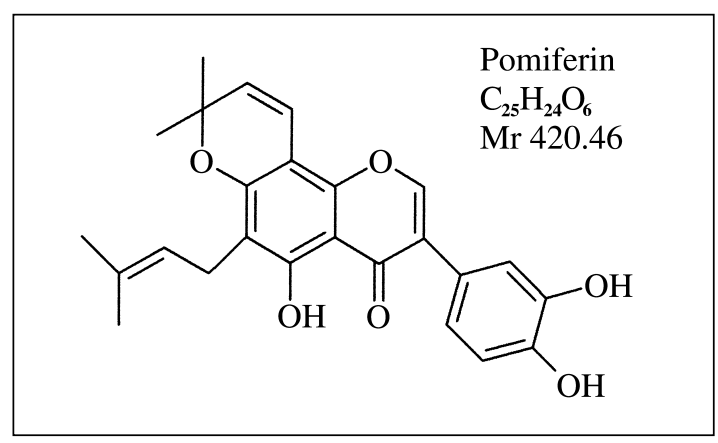

Fig. 1. Chemical structure of pomiferin

In vitro studies of the antioxidant abilities of pomiferin were performed: the peroxynitrite and DPPH (diphenyl-picryl-hydrazyl) radical scavenging activity. The Fe(II)/NADPH enhanced lipid peroxidation test in the rat liver microsomal fraction was done. Mouse hepatic microsomes were used to determine the EROD activity (7-ethoxyresorufin-Odeethylase) of pomiferin (Ves elá et al. 2003).

An in vivo pilot study confirmed the scavenging potential of pomiferin (Bartošík ová et al. 2003). The aim of the present study was to analyse the relation between the antioxidant effect and the applied dose of pomiferin during a prophylactic administration under the conditions of ischemia-reperfusion of the kidney tissue in the laboratory rat.

The study and its experimental protocol were approved and monitored by the Ethics Committee of the University of Veterinary and Pharmaceutical Sciences Brno. The experiment was performed by a work group whose members are holders of the Certificate on Professional Competence issued by the Central Commission for Animal Protection pursuant to $\S 17$ of the Act on Protection of Animals against Cruelty (No 246/1992 Coll.) of the Czech National Council.

\section{Materials and Methods}

Fifty male Wistar SPF laboratory rats (origin - AnLab s.r.o. Germany) were used in the study. All animals were of the same age and comparable weight $(250 \pm 10 \mathrm{~g})$. They were housed in a room with standard temperature and 
light regime, fed a diet for small laboratory animals, and watered ad libitum (complete diet for laboratory mice and rats in SPF breedings - M1; origin - Ing. F. Náchal, VKS Jiř́íkov, Czech Republic, Reg. No. 10250). After 10 days of acclimatization, the animals were randomly divided in 5 groups $(n=10)$ : three premedicated groups, a placebo group, and an intact group.

Pomiferin, 3 - (3, 4-dihydroxy-phenyl) - 5-hydroxy - 8,8-dimethyl - 6-(3-methyl - but - 2-enyl) - 8H-pyrano[2,3f]chromen - 4 - one, was isolated from the fruits of Maclura pomifera (Raf.) Schneid. (Moraceae), and its purity was HPLC-proved (Lišk ová et al. 2005). For the testing, pomiferin was always suspended in $2 \mathrm{ml}$ of $0.5 \%$ Avicel solution (microcrystalline cellulose). Pomiferin was administered to the premedicated groups et doses of 5, 10 and $20 \mathrm{mg} \cdot \mathrm{kg}^{-}$ ${ }^{1}$ orally by a gastric sound once a day. The placebo group received only $2 \mathrm{ml}$ of $0.5 \%$ Avicel solution in the same way as the premedicated groups. The intact group was left without any medication. After 15 days of premedication, laparotomy under general anaesthesia $(2 \%$ Rometar $0.5 \mathrm{ml}+$ Narkamon $10 \mathrm{ml}$, dose $0.5 \mathrm{ml}$ solution $/ 100 \mathrm{~g}$ of the rat body mass) was performed, ischemia-reperfusion injury was induced by applying a vascular clamp on the left renal artery for $60 \mathrm{~min}$ with a subsequent $10 \mathrm{~min}$ renal reperfusion. After the reperfusion, the animals were exsanguinated by blood collection from the left ventricle and selected biochemical markers were analysed - superoxide dismutase (SOD, EC 1.15.1.1) in erytrocytes (Arthur and Valentine 1985), glutathion peroxidase (GSHpx, EC 1.11.1.9) in heparinized blood (Paglia 1967), total antioxidative capacity (AOC) in heparinized plasma (Miller et al. 1993), using RANDOX testing kits (Dublin, Ireland) in COBAS MIRA S automatic analyser, and malondialdehyde (MDA) in serum was analysed spectrophotometrically using the TBARs method (Kosugi and Kikugawa 1989).

The kidney tissue samples were fixed in $10 \%$ formaldehyde and processed manually. Two blocks were made of each sample, the sections stained with hematoxylin-eosin. All the evaluated samples were of outstanding quality, the evaluation was performed by a histopathologist without knowledge of the experimental protocol. Evaluation principle: all the samples of the material were evaluated and scored separately in 3 kidney tissue structures, the results were added up and in the end the average score of each medicated group was determined.

Scoring schedule

In the first tissue structure - kidney medulla - the level of tissue destruction through bleeding (by the extent) and the presence of an inflammatory infiltrate $(\max .+++)$ were evaluated.

In the second tissue structure - cortex and glomerules - the extraglomerular $(+)$ presence of haemorrhages and the increased cellularity and extravasates in the glomerule (max. ++ ) were both evaluated.

In the third tissue structure - kidney tubules - the presence of regressive changes of epithelia from oedema to necrosis was evaluated ( + in the case of necrosis and \pm in the case of regression not reaching the level of necrosis). In addition, the channel content was evaluated (protein and hyaline cylinders + ). Maximum ++ .

The most extensive damage - the highest possible score per one sample was $7(7$ times + ).

The results were processed by the Microsoft ${ }^{\circledR}$ Excel $^{\circledR}$ table processor and statistically interpreted using a nonpair T-test. The value $p \leq 0.05$ was considered significant.

\section{Results}

\section{Results of the biochemical examination Biochemical results are given in Table 1.}

Table 1. Results of biochemical determination, values expressed as $\mathrm{x} \pm \mathrm{SD}$

\begin{tabular}{|c|c|c|c|c|c|}
\hline \multicolumn{2}{|c|}{$\begin{array}{l}\text { Group of animals } \\
\qquad(\mathrm{n}=10)\end{array}$} & $\begin{array}{c}\text { SOD } \\
(\mathrm{U} / \mathrm{ml})\end{array}$ & $\begin{array}{l}\text { GSHPx } \\
(\mu \mathrm{kat} / \mathrm{L}) \\
\end{array}$ & $\begin{array}{c}\mathrm{AOC} \\
(\mathrm{mmol} / \mathrm{L})\end{array}$ & $\begin{array}{c}\mathrm{MDA} \\
(\mathrm{mmol} / \mathrm{L})\end{array}$ \\
\hline \multirow{3}{*}{ 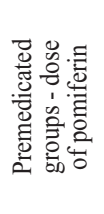 } & $\begin{array}{c}5 \\
\mathrm{mg} \cdot \mathrm{kg}^{-1} \\
\end{array}$ & $156.58 \pm 14.34 * *++$ & $1980.20 \pm 311.44$ & $0.43 \pm 0.03 *$ & $2.33 \pm 0.54 * *++$ \\
\hline & $\begin{array}{c}10 \\
\mathrm{mg} \cdot \mathrm{kg}^{-1}\end{array}$ & $177.35 \pm 13.57^{* *}++$ & $2350.50 \pm 252.32++$ & $0.43 \pm 0.07$ & $1.88 \pm 0.41^{* *++}$ \\
\hline & $\begin{array}{c}20 \\
\mathrm{mg} \cdot \mathrm{kg}^{-1}\end{array}$ & $164.83 \pm 2.81 * *++$ & $2370.90 \pm 295.56++$ & $0.36 \pm 0.07$ & $1.48 \pm 0.68 * *$ \\
\hline \multicolumn{2}{|c|}{ Placebo group } & $63.24 \pm 3.57$ & $2180.40 \pm 376.02$ & $0.39 \pm 0.05$ & $11.95 \pm 4.55 \bullet \bullet$ \\
\hline \multicolumn{2}{|c|}{ Intact group } & $58.82 \pm 2.76$ & $1821.60 \pm 205.07$ & $0.40 \pm 0.06$ & $1.01 \pm 0.52$ \\
\hline \multicolumn{3}{|c|}{$\begin{array}{l}* p \leq 0.05 \text { premedicated vs placebo group } \\
+p \leq 0.05 \text { premedicated vs intact group } \\
\cdot p \leq 0.05 \text { placebo vs intact group }\end{array}$} & $\begin{aligned} p & \leq 0.01 \text { premedica } \\
+p & \leq 0.01 \text { premedica } \\
p & \leq 0.01 \text { placebo } \mathrm{V}\end{aligned}$ & $\begin{array}{l}\text { lacebo group } \\
\text { intact group } \\
\text { group }\end{array}$ & \\
\hline
\end{tabular}

A highly significant increase of SOD activities $(p \leq 0.01)$ was detected in the groups premedicated with pomiferin at doses of 5,10 , and $20 \mathrm{mg} \cdot \mathrm{kg}^{-1}$, compared with the placebo 
and the intact groups. Comparison of the SOD activities obtained from the groups premedicated with doses of 5 and $10 \mathrm{mg} \cdot \mathrm{kg}^{-1}$ showed a highly significant difference ( $p \leq$ 0.01 ), and the difference between the groups premedicated with 10 and $20 \mathrm{mg} \cdot \mathrm{kg}^{-1}$ was significant $(p \leq 0.05)$.

A significant increase in GSHPx activities $(p \leq 0.01)$ was detected in the groups premedicated with doses of 10 and $20 \mathrm{mg} \cdot \mathrm{kg}^{-1}$, compared with the intact group. Comparison of the GSHPx activities obtained from the groups premedicated with doses of 5 and $10 \mathrm{mg} \cdot \mathrm{kg}^{-1}$ showed a significant difference $(p \leq 0.01)$, as did the comparison between the groups premedicated with doses of 5 and $20 \mathrm{mg} \cdot \mathrm{kg}^{-1}(p \leq 0.01)$.

An increase of AOC values $(p \leq 0.05)$ was detected only in the group premedicated with doses of $5 \mathrm{mg} \cdot \mathrm{kg}-1$, compared with the placebo group. Comparison of AOC values obtained from the groups premedicated with doses of 5 and $20 \mathrm{mg} \cdot \mathrm{kg}^{-1}$ showed a significant difference $(p \leq 0.05)$, as did the comparison between the groups premedicated with doses of 10 and $20 \mathrm{mg} \cdot \mathrm{kg}^{-1}(p \leq 0.05)$.

A significant decrease of MDA values $(p \leq 0.01)$ was detected in the groups premedicated with doses of 5,10 , and $20 \mathrm{mg} \cdot \mathrm{kg}^{-1}$, compared with the placebo group. Furthermore, a significant difference in MDA values $(p \leq 0.01)$ was found in the groups premedicated with doses of 5 and $10 \mathrm{mg} \cdot \mathrm{kg}^{-1}$ in comparison with the intact animal group. Comparison of the values obtained from the placebo group and the intact animal group showed an increase $(p \leq 0.01)$ of the MDA value in the placebo group, which is the result of the pathological state induction.

Results of the histopathological examination

General evaluation

In all groups, destructive and regressive changes predominated with a very small inflammatory component, which was rather observed in the samples with a high score value ( 5 and more); it may be considered as a response to the presence of necrosis and tissue destruction through bleeding.

Specific results of premedication

The premedicated groups

The optimal protective effect appeared with the $5 \mathrm{mg} \cdot \mathrm{kg}^{-1} \mathrm{dose}$ of pomiferin, in all three tissue structures (average score per one sample: 1.9, 1.1 and 1.2).

The placebo group

In all samples massive haemorrhages in the interstitium were observed, especially at the cortex and medulla borders; there was haemorrhage in the glomerule area (Bowman's capsule and capillary convolution) as well as in the medulla. The tubules had regressively changed epithelia from a simple oedema to an epithelial necrosis, with all the above described features. In the lumina there was mostly a proteinaceous content with a hyaline cylinder formation. The accompanying oedema and generally increased cellularity of the glomerule were inflammatory. The more marked inflammatory infiltrate was smaller than in the premedicated groups in the form of sporadic lymphocytes with rare polynuclears. The total average score was oscillating from 5 to 7 .

The intact group

Haemorrhage occurred only accidentally, most probably in result of contusion.

\section{Discussion}

Intensive ischemia causes necrosis and long-lasting milder ischemia triggers apoptosis. Ischemia of the kidney tissue might be the direct cause of an acute renal failure. 
Prenylated isoflavonoid pomiferin is an isolated substance which was only rarely tested in vitro (Veselá et al. 2003) or in vivo (Bartošíko vá et al. 2003, 2004; Nečas et al. 2004; Janoštíková et al. 2004). Its antioxidant effect could be achieved by several mechanisms. According to its structure it could chelate copper and iron which are potential inducers of Fenton reaction, and it could also inactivate xanthin oxidase. Generally, flavonoids are able to inactivate hydrogen peroxide, peroxyl radicals and thus protect lipids against lipoperoxidation, inhibit the activation of phospholipase A2 and the degradation of arachidonic acid in lipid membranes. They are able to keep the physiological range of an inflammatory reaction.

In our study, the relation between the antioxidant effect and the dose of pomiferin used for prophylactic administration under the conditions of kidney ischemia-reperfusion in the laboratory rat was analysed. Antioxidant abilities of pomiferin were judged by its ability to affect the activities of antioxidant enzymes (SOD, GSHPx), the concentration of lipid bymetabolite MDA, and to influence AOC.

The statistically significant higher SOD activities found in the premedicated groups confirm the readiness of the organism to destroy superoxide. There was no linear relation between the dose of pomiferin and the activity of SOD. The highest effect on SOD activity increase was declared with the middle dose $-10 \mathrm{mg} \cdot \mathrm{kg}^{-1}$.

Statistically non-significant was the increase of GSHPx activities in all the premedicated groups. The highest dose - $20 \mathrm{mg} \cdot \mathrm{kg}^{-1}$ - was the most effective one.

Since the analysed enzymes are intracellular and their activities follow one another, we may suppose that their activities are influenced by the type of ROS that is just present. Pomiferin could co-operate in scavenging actions and thus influence the level of an irritating type of ROS. We may also assume that the prophylactic administration of pomiferin could influence the readiness of the organism to produce antioxidant enzymes. The detailed mechanisms of these supposed actions are unknown. But the fact is that in the placebo group where the reaction against an ischemic injury is supposed to be physiological, the activities of the assessed enzymes were lower than in the premedicated groups, although only nonsignificantly. Pomiferin could regenerate natural antioxidants such as alpha-tocopherol, ascorbic acid or other antioxidative enzyme - catalase - which was not assessed in our study, but which could participate in the scavenging of hydrogen peroxide. The views on the change of SOD and GSHPx activities caused by kidney hypoxia vary - some authors declare increased activities (Chen et al. 1996), others decreased activities (Racek et al. 1995), or unaffected activities (Ď u račková 1997) of these enzymes. It is necessary to respect the fact that the antioxidant mechanisms in the organism are complex, and any imbalance including the addition of a potentially antioxidant agent must be compensated. The reactivity of the antioxidant system in the organism is also limited by the quantity of substances such as NADPH, which is necessary for the regeneration of oxidized glutathione. The production of NADPH in erytrocytes is limited by the presence of enzymes such as glucose-6phosphodehydrogenase. In this sense the lifetime and metabolic activity of erytrocytes could influence the antioxidant abilities of the organism (Štípek 2000).

AOC is not the most specific criterion for the antioxidant abilities of the organism. It is a sum of the effects of many antioxidant factors. It is necessary to search for the main factor. Uric acid which is the final product of the degradation of AMP is a very important antioxidant in blood. The interruption of the respiration chain during the ischemic period causes a cumulation of AMP which is the source of uric acid. Flavonoids or other compounds with a potential antioxidant effect usually increase AOC (Toborek et al. 1992). Premedication with pomiferin et doses of $5 \mathrm{mg} \cdot \mathrm{kg}^{-1}$ and $10 \mathrm{mg} \cdot \mathrm{kg}^{-1}$ increase AOC nonsignificantly and et the dose of $20 \mathrm{mg} \cdot \mathrm{kg}^{-1}$ even decreased AOC.

MDA is a toxic by-product of lipid peroxidation and its concentration usually correlates 
with the intensity of action of ROS in lipid membranes and thus also with the severity of an oxidative injury. Many authors declare an increased concentration of MDA. But the reason for this increase could also be the decreased renal elimination of this lipid peroxidation product during a renal failure. Moreover, the TBARs method (Kosugi and Kikugava 1989) with the spectrophotometrical assessment is not the most specific one. Numerous other chemical substances present in blood react with the thiobarbituric acid - glucose, amino acids, creatinine, uric acid and many others - and the products of this reaction also absorb at $530-535 \mathrm{~nm}$. There are different ways to eliminate these products; the most effective one is probably HPLC (Zima et al. 1995). In any case, the most important result of the measurement of MDA concentrations is the difference between the assessed concentrations in the premedicated groups and the placebo or intact groups. Considering this fact, we may say that the traditional assessment (without HPLC) is sufficient for our measurements. Statistically highly significant decrease of MDA concentrations in all premedicated groups was recorded in our study. This result correlates with the idea of inhibition of lipoperoxidation by flavonoids - in our case pomiferin. The best result was achieved after the administration of the highest dose of pomiferin $-20 \mathrm{mg} \cdot \mathrm{kg}^{-1}$.

Histopathological results can describe the measure of damage with true exactness. There were mostly destructive changes it this type of experiment where the reperfusion after 60 min ischemia lasted only $10 \mathrm{~min}$. The placebo group with mostly massive haemorrhages reached $5-7$ points. The premedicated groups achieved much better results, the best one was recorded after the administration of pomiferin at the dose of $5 \mathrm{mg} \cdot \mathrm{kg}^{-1}$.

Biochemical and histopathological results correlated and confirmed the antioxidant abilities of pomiferin. The relation between the dose and the effect was not linear and some of the assessed differences between the groups were statistically highly significant. The best biochemical results were achieved by the group premedicated with pomiferin at the dose of $20 \mathrm{mg} \cdot \mathrm{kg}^{-1}$, and the histopathological examination confirmed the dose of $5 \mathrm{mg} \cdot \mathrm{kg}^{-1}$ to be the most effective one.

The results of this study will contribute to the pool of knowledge on the effects of prenylated flavonoid pomiferin, and may be updated in the future. It will be useful to judge its antioxidant abilities by the effect on other markers of oxidative stress, e.g. the rate of oxidized and reduced glutathione or the activity of catalase; a detailed examination of the kidney functions is necessary. The effect on the therapy of ischemia-reperfusion injury will be examined as well.

\section{Efekt pomiferinu v profylaxi oxidačního poškození u ischemie-reperfuze ledviny laboratorního potkana}

Cílem této práce bylo stanovení závislosti účinku na dávce profylakticky podávaného flavonoidu pomiferinu. Patologickým modelem pro testování in vivo byla ischemiereperfuze ledviny laboratorního potkana. Zviřrata byla metodou náhodného výběru rozdělena do pěti skupin. Testovaný pomiferin byl suspendován vždy ve $2 \mathrm{ml} 0.5 \%$ roztoku Avicelu, podáván byl perorálně, gastrickou sondou, v dávkách 5, 10 a $20 \mathrm{mg} \cdot \mathrm{kg}^{-1}$ jednou denně třem premedikovaným skupinám. Čtvrté skupině bylo stejnou cestou aplikováno placebo - $2 \mathrm{ml} 0.5 \%$ roztoku Avicelu, pátá skupina byla kompletně intaktní. Premedikace trvala 15 dní, následně byla v celkové anestézii navozena ischémie levé ledviny na dobu 60 min. Reperfuze trvala 10 min, byla ukončena odběrem krve z levé komory srdeční a odběrem reperfundované ledviny. $\mathrm{V}$ krvi byly měřeny hladiny těchto biochemických markerů: superoxid dismutáza, glutathion peroxidáza, celková antioxidační kapacita a malondialdehyd. Vzorky reperfundované ledvinné tkáně byly podrobeny histopatologickému vyšetření. Laboratorní i histopatologické výsledky studie potvrdily předpokládané účinky pomiferinu. Ty se projevují podporou vlastní obranné reakce organismu na zvýšenou produkci volných radikálů a brzdí procesy peroxidace lipidů membrán, což 
přispívá $\mathrm{k}$ udržení vitality filtračního aparátu ledvin. Závislost účinku na podané dávce pomiferinu nebyla lineární a některé rozdíly mezi skupinami byly statisticky vysoce významné $(p \leq 0.01)$. Nejlepších výsledků biochemických vyšetření bylo dosaženo po podání pomiferinu v dávce $20 \mathrm{mg} \cdot \mathrm{kg}^{-1}$. Z hlediska histopatologického byla nejefektivnější dávka $5 \mathrm{mg} \cdot \mathrm{kg}^{-1}$.

\section{Acknowledgements}

The study was supported by the grant of IGA MZ ČR - NL/7455-3.

\section{References}

ARTHUR JR, VALENTINE WN 1967: Superoxide dismutase and glutathione peroxidase activities in neutrophils from selenium deficient and copper deficient cattle. Lif Sci 36: 1569-1575

BARTOŠÍKOVÁ L, NEČAS J, PAVLÍČEK V, KUCHTÍČKOVÁ S, FRÁŇA P, ZAVADILOVÁ R, HUŠEK K 1998: Study of the effect of the sympatolytic carvedilol in the conditions of experimental alloxan diabetes in the laboratory rat. Cs a slov Farm 47: 151-154

BARTOŠÍKOVÁ L, NEČAS J, SUCHÝ V, JANKOVSKÁ D, LIŠKOVÁ M, KOLLÁR P, KOTOLOVÁ H, BARTOŠÍK T, STRNADOVÁ V, BARTOŠOVÁ L, FLORIAN T, FRYDRYCH M, KLUSÁKOVÁ J 2003: Testování antioxidačního efektu pomiferinu v pilotní studii. 53. Farmakologické dny, Brno, 10. - 12. zář́i 2003 (Abstract In: Československá fyziologie, 2003, 52: 4)

BARTOŠÍKOVÁ L, NEČAS J, SUCHYY V, KUBÍNOVÁ R, LIŠKOVÁ M, FLORIAN T, KOLLÁR P, KOTOLOVÁ H, MAZÁNKOVÁ D, BARTOŠÍK T, KLUSÁKOVÁ J, JANOŠTÍKOVÁ E, GÖPFERT E, BARTOŠOVÁ L, STRNADOVÁ V 2004: Antioxidative effect of pomiferine in ischemia-reperfusion of laboratory rat kidney tissue (effect in prophylaxis). Jahrestagung-Joint Meeting 2004, Regensburg, SRN, October 6-9, 2004 (Abstract In: ISBN: 3-00-014723-3)

BARTOŠOVÁ L, FRYDRYCH M, MOKRÝ P, BRUNCLÍK V, KOTOLOVÁ H 2003: Changes in heart rate after application of newly developed ultrashort acting beta-adrenergic blockers. Pharmazie 58: 841-42

BULKLEY GB 1987: Free radical mediated reperfusion injury: a selective review. Br J Cancer 8: 66-73 (Suppl.)

DRÁBIKOVÁ K, NOSÁL R, JANČINOVÁ V, ČÍŽ M, LOJEK A 2002: Reactive oxygen metabolite production is inhibited by histamine and H1-antagonist dithiaden in human PMN leukocytes. Free Radic Res 36: 975-980

ĎURAČKOVÁ Z 1997: Antioxidanty v dobrom aj zlom. Clin Biochem Met 5:194-199

CHEN ZY, CHAN PT, HO KY, FUNG KP, WANG J 1996: Antioxidant activity of natural flavonoids is governed by number and location of their aromatic hydroxyl groups. Chem Phys Lipids 79: 157-163

JANOŠTÍKOVÁ E, BARTOŠÍKOVÁ L, NEČAS J, JUŘICA J, FLORIAN T, FRYDRYCH M, KLUSÁKOVÁ J, BARTOŠÍK T 2004: Testování antioxidačního efektu pomiferinu v preklinickém pokusu. MEFA kongres 2004, MediFórum, Brno, 03. 11. 2004 (ISSN: 80-86607-13-5)

KOSUGI H, KIKUGAWA K 1989: Potential thiobarbituric acid-reactive substances in peroxidized lipids. Free Radic Biol Med 17: 205-207

LIŠKOVÁ M, MAREK J, JANKOVSKÁ D, SUKUPOVÁ L, ŽEMLIČKA M, VANČO J 2005: Osajin. Acta Crystal 61: 01848 - 01850 (in press)

MILLER NJ, RICE-EVANS C, DAVIES M 1993: A novel method for measuring antioxidant capacity and its application to monitoring the antioxidant status in premature neonates. Clin Sci 84: 407-412

NEČAS J, BARTOŠÍKOVÁ L, DRÁPELOVÁ L, HUSEK K, PAVLÍČEK V, KUCHTIČKOVÁ S 1997: The effects of Carvedilol, a beta-blocker, in experimental ischemia-reperfusion kidney injury. Vnitr Lek 43: 707-711

NEČAS J, BARTOŠÍKOVÁ L, SUCHÝ V, KUBÍNOVÁ R, LIŠKOVÁ M, BARTOŠÍK T, JANOŠTÍKOVÁ E, FLORIAN T, FRYDRYCH M, KRČMÁŘ J, KLUSÁKOVÁ J, PARÁK T, GÖPFERT E 2004: Antioxidative effect of pomiferine in ischemia-reperfusion of laboratory rat kidney tissue (effect in therapy). Jahrestagung Joint Meeting 2004, Regensburg, SRN, October 6-9, 2004 (Abstract In: ISBN: 3-00-014723-3)

PAGLIA DE, VALENTINE WN 1967: Studies on the quantitative and qualitative characterization of erythrocyte glutathione peroxidase. J Lab Clin Med 70: 158-69

PEČIVOVÁ J, MAČIČKOVÁ T, ČİŽ M, NOSÁL R, LOJEK A 2004: Effect of stobadine on opsonized zymosan stimulated generation of reactive oxygen species in human blood cells. Physiol Res 53: 97-102

RACEK J, VESELÁ E, HOLEČEK V, TǨEŠKA V 1995: The significance of free radicals in patients with renal insufficiency and kidney transplantation. Klin Biochem Met 3: 4-6

RICE-EVANS C 1995: Plant polyphenols: free radical scavengers or chain-breaking antioxidants? Biochem Soc Symp 61: 103-116

ROY RS, McCORD JM 1982: Ischemia induced conversion of xanthine dehydrogenase to xanthine oxidase. FASEB J 41: 767-773

SERTESER M, KOKEN T, KAHRAMAN A, KERIMAN Y, AKBULUT G, DILEK ON 2002: Changes in hepatic TNF- $\alpha$ levels, antioxidant status, and oxidation products after renal ischemia/reperfusion injury in mice. J Surg Res 107: 234-240 
SHIMIZU MHM, ARAUJO M, BORGES SMM, de TOLOSA EMC, SEGURO AC 2004: Influence of age and vitamin $\mathrm{E}$ on post-ischemic acute renal failure. Exp Gerontol 39: 825-830

SINGH D, CHOPRA K 2004: The effect of naringin, a bioflavonoid on ischemia-reperfusion induced renal injury in rats. Pharmacol Res 50: 187-193

ŠTÍPEK S 2000: Antioxidanty ve zdraví a nemoci (Antioxidants in health and disease). Grada Publishing, Prague, 60-72 p.

TOBOREK M, WASIK T, DRÓZDZ M, KLIN M, MAGNER-WRÓBEL K, KOPIECZNA-GRZEBIENIAK E 1992: Effect of hemodialysis on lipid peroxidation and antioxidant system in patients with chronic renal failure. Metabolism 41: 1299-1232

Van HOORN DEC, NIJVELDT RJ, Van LEEUWEN PAM, HOFMAN Z, M'RABET L, De BONT DBA, NORREN KV 2002: Accurate prediction of xanthin oxidase inhibition based on the structure of flavonoids. Eur J Pharmacol 451: 111-118

VESELÁ D, KUBÍNOVÁ R, MUSELÍK J, ŽEMLIČKA M, SUCHÝ V 2003: Antioxidative and EROD activities of osajin and pomiferin. Fitoterapia 75: 2029-211

ZIMA T, ŠTÍPEK S, CRKOVSKÁ J, PLÁTENÍK J 1995: Stanovení produktu lipoperoxidace - malondialdehydu - v biologickém materiálu spektrofotometricky a HPLC (Spectrophotometrical and HPLC assessment of the lipoperoxidation product - malondialdehyde - in biological samples). Klin Biochem Met 3: 98-102 